lines too short.

All higher education institutions, not just those tertiary institutions with vocational missions, are increasingly held accountable for matching their education offerings with workforce needs and the employability of their graduates. This has led to the steady "vocationalization" of higher education at the undergraduate level.

The dangers of designing higher education curricula for immediate usefulness are real. Gearing degrees to the contemporary workplace and training students for specific jobs can potentially pave the way to chronic unemployment. The forces of globalization and new discoveries can shutter factories, bypass entire industries, and throw graduates who are narrowly educated on the slag pile of human obsolescence.

While we need not return to the Studium Generale to be true to higher education's core mission, it is time to consider how to balance relevance with timelessness and shortterm usefulness with long-term competency. As we look to the future, we need to reckon with what "useful" means in considering higher education's obligations to its students and society. If the core mission is to educate students well for a lifetime, its usefulness will include an intellect developed for a personally rewarding life, the wherewithal for informed citizenship, and the ability to move productively between multiple jobs and careers.

Great universities and well-developed higher education systems will legitimately be asked to respond to societal needs. The challenge will be in managing those demands without losing the very thing that has made them great.

\section{Chinese Higher Education: Future Challenges}

\section{Gerald A. Postiglione}

Gerard A. Postiglione is chair professor and associate dean, Faculty of Education, University of Hong Kong. E-mail: gerry.hku@gmail.com.

For 2020, the key question is: Will China be a major or fractional power in international higher education with a unique and exportable university model? Several contemporary book titles indicate that it is a question worth asking: When China Rules the World; The Post-American World and the Rise of the Rest; Will China dominate the 21st Century?

As China inches toward becoming the world's largest economy, there are indications of an economic slowdown and concern about how this will affect higher education. China already has the most students in higher education, more scientific publications, and a larger budget for research and development than any country in the world, except the United States. Several flagship universities have gained a world-class ranking, though the system as a whole does poorly on quality indicators. It bodes well for the future of Chinese higher education, which prospective students in its largest city outperform counterparts in mathematics and science in a 6o-country Organization for Economic Cooperation and Development assessment.

While the debate continues in China about how to build a unique university model to compliment the Beijing Consensus, efforts to shape universities with indigenous ideas are stymied by the race for global rankings. Meanwhile, universities struggle with uninspiring teaching that is reflected in media outlets that report students are sleeping through lectures. Recent research shows many teachers liven up their classes by criticizing government and the Communist Party, leading to a call for more teaching of Marxism. China's leaders also understand that its universities are not only instruments of knowledge creation and dissemination, but also instruments of international competition. Initiatives are under way to foster soft skills in the science, technology, engineering, and mathematics fields to drive industrial innovation and China's economic globalization. Despite such efforts, the transition to mass higher education is plagued by a burgeoning of unemployed graduates.

The global influence of China's universities in 2025 will hinge on how it handles a precarious balance between domestic demands and aspirations to go global. The domestic demands include those by employers for knowledge and skills to upgrade production, by urban, middle-class households for status culture that distinguished their children, and by the rural poor, migrants, and minorities for equitable access and jobs. These demands remain subsidiary to the state's demand for national prosperity, power and strength, stability and unity. The state orchestrates the aspirations of universities to going global by demanding that internationalization does not sacrifice educational sovereignty, even while the state must eventually cede more autonomy to universities.

By 2020 , more Chinese citizens will have a college education than the entire workforce of the United States. While sending more students to the United States than any other country, China itself is fast becoming one of the most popular international destinations for overseas study. Harvard's Vogel may be right that the result of China's opening and reform for higher education has been an intellectual vitality as broad and deep as the Western Renaissance. But the extent to which China will have a unique and exportable model that powers international higher education in 2020 remains a key question. 